\title{
TINGKAT PERTUMBUHAN DAN KELANGSUNGAN HIDUP, PADA PEMBESARAN UDANG GALAH (Macrobrachium rosenbergii de Man 1879) STRAIN SIRATU DAN STRAIN GIMACRO II
}

\author{
Level of Growth, and Survival Rate at Giant Prawn Enlargement (Macrobrachium rosenbergii de \\ Man 1879) Siratu Strain and Strain GIMacro II
}

\author{
Albert Parulian Manurung ${ }^{1}$, Indah Anggraini Yusanti ${ }^{2}$, dan Rangga Bayu Kusuma Haris ${ }^{2}$ \\ 1) Alumni Fakultas Perikanan Universitas PGRI Palembang \\ 2) Staf Pengajar Fakultas Perikanan Universitas PGRI Palembang \\ Email : perikanan.pgri@gmail.com
}

\begin{abstract}
Abstrak
Udang Galah (Macrobrachium rosenbergii de Man 1879) merupakan udang yang paling populer dari keseluruhan udang air tawar dikarenakan ukuran tubuhnya yang besar dan memiliki nilai ekonomi yang tinggi baik di pasar domestik maupun luar negeri. Pada Tahun 2014 dan 2015 KKP Merilis hasil Pemulian Strain Baru yaitu GIMacro II dan Siratu. Kedua strain ini memiliki silsilah yang berbeda dan perlu melihat tingkat pertumbuhan, dan kelangsungan hidup dari kedua strain tersebut. Penelitian ini dilaksanakan selama 90 hari pada Bulan September-November 2017 bertempat di Instalasi Pembenihan Udang Galah (IPUG) Balai Besar Perikanan Budidaya Air Tawar (BBPBAT) Sukabumi, Jalan Raya Cisolok KM.12 Desa Karangpapak Pelabuanratu, Provinsi Jawa Barat. Penelitian ini menggunakan Rancangan Acak Lengkap (RAL) dengan 3 (tiga) taraf perlakuan, masing-masing perlakuan dilakukan 3 (tiga) kali ulangan, yaitu P1 (Strain Siratu 100\%), P2 (Strain GIMacro II 100\%), dan P3 (Strain Siratu $50 \%$ dan Strain GIMacro II 50\%). Wadah yang digunakan dalam penelitian ini berbentuk bak persegi panjang berukuran 3x5 m. Hasil penelitian Menunjukkan bahwa P1 (Strain Siratu 100\%) memberikan hasil terbaik yaitu pertumbuhan panjang sepanjang 10,14 cm serta pertambahan bobot sebesar 19,75 gram dan kelangsungan Hidup sebesar 72,89\%.
\end{abstract}

Kata Kunci : Udang Galah, Pertumbuhan dan Kelangsungan Hidup.

\begin{abstract}
Giant Prawns was the most popular shrimps of whole freshwater shrimp due to their large body size and have high economic value both in domestic and foreign markets. In 2014 and 2015 KKP has realesed a new strain breeding result were GIMacro and Siratu. The strains have different pedigrees and need to see growth, and survival rate level of both strains. This research was conducted for 90 days in SeptemberNovember 2017 at the Installation of Galah Udang Galah (IPUG) of freshwater aquaculture (BBPBAT) Sukabumi, Jalan Raya Cisolok KM.12 Karangpapak Pelabuanratu Village, West Java Province. This research used a Completely Randomized Design (RAL) with 3 (three) treatment levels, each treatment performed 3 (three) replicates, treatment P1 (Siratu Strain 100\%), P2 (100\% GIMacro Strains), and P3 $50 \%$ Siratu Strain and 50\% GIMacro Strain). The container used in this research was a rectangular tube measuring $3 \times 5 \mathrm{~m}$. The results showed that P1 (Siratu Strain 100\%) gave the best result that is the length growth along the 10,14 cm and the weight gain 19,75 gram and survival rate 72,89\%.
\end{abstract}

Keywords: Giant Prawns, Growth, and Survival rate 


\section{PENDAHULUAN}

Udang merupakan komoditas ekspor hasil perikanan Indonesia keempat di bawah komoditas ikan tuna, cakalang, dan tongkol yang menempati urutan ketiga. Hal ini dapat dilihat dari data ekspor udang Indonesia ke mancanegara pada tahun 2016 volume ekspor udang mencapai 196.623 ton sedangkan volume ekspor ikan tuna, cakalang dan tongkol mencapai 206.553 ton (Badan Pusat Statistik, 2016). Udang Galah (Macrobrachium rosenbergii de Man 1879) adalah salah satu spesies udang air tawar asli Indonesia. Udang Galah (Macrobrachium rosenbergii de Man 1879) merupakan udang yang paling populer dari keseluruhan udang air tawar dikarenakan ukuran tubuhnya yang besar dan memiliki nilai ekonomi yang tinggi baik di pasar domestik maupun luar negeri (Priyono et al., 2011).

Budidaya Udang Galah (Macrobrachium rosenbergii de Man 1879) mengalami perkembangan yang cukup pesat, khususnya pada sektor pembesaran. Menurut Effendi (2004) dalam Iswandi et al, (2014), mengemukakan bahwa pertumbuhan merupakan perubahan bentuk, baik panjang walaupun berat sesuai dengan perubahan waktu. Nilai konversi sebagai salah satu alat ukur performa stock parental Udang Galah (Macrobrachium rosenbergii de Man 1879) merupakan indikator kemampuan kultivan untuk merubah pakan yang diberikan untuk proses pertambahan berat sekaligus indikator terhadap resposibilitas terhadap jenis pakan yang diberikan (Kisworo dan Mukhlisah, 2015).

Kelangsungan hidup sudah lama menjadi penyebab terhambatnya budidaya Udang Galah (Macrobrachium rosenbergii de Man 1879), kelangsungan hidup dalam budidaya Udang Galah (Macrobrachium rosenbergii de Man 1879) tidak lebih dari 15-20\%. Rendahnya kelangsungan hidup pada pembenihan Udang Galah (Macrobrachium rosenbergii de Man 1879) dipengaruhi banyak faktor, antara lain pemilihan induk, cara budidaya, sifat udang yang kanibal, kualitas air dan pakan (Ali, 2009 dalam Sutjinurani et al., 2013). Kerentanan larva terhadap penyakit dan lambatnya pertumbuhan udang pada fase pembesaran di kolam diduga sebagai dampak dari manajemen induk yang salah. Pada umumnya hatchery menggunakan induk dari hasil pembesaran sendiri tanpa memperhatikan kaidah memproduksi induk yang seharusnya (Rohmana, 2017).

Menurut Priyono et al (2011), pada tahun 2001 Departemen Kelautan dan Perikanan menetapkan Udang Galah (Macrobrachium rosenbergii de Man 1879) sebagai salah satu alternatif komoditas unggulan. Kebijakan ini diambil bersamaan dengan rilisnya varietas udang galah yang dikenal sebagai Udang Galah GIMacro (Genetic Improvement of Macrobrachium rosenbergii). GIMacro merupakan varietas Udang Galah (Macrobrachium rosenbergii de Man 1879) yang berasal dari tiga subpopulasi, yaitu udang galah dari Kalipucang (Ciamis), Cimanuk (Bekasi), dan sungai Musi (Palembang) (Khairuman dan Amri, 2004 dalam Evan, 2009).

Kenudian pada tahun 2014, dilanjutkan kembali pemuliaan varietas guna memperkaya jenis dan varietas udang galah yang beredar di masyarakat telah dihasilkan Udang Galah (Macrobrachium rosenbergii de Man 1879) GI Macro II yang merupakan hasil kegiatan pemuliaan udang galah melalui seleksi individu pada karakter pertumbuhan berdasarkan panjang standar yang dilakukan oleh Balai Penelitian Pemuliaan Ikan Sukamandi. Strain Udang Galah (Macrobrachium rosenbergii de Man 1879) GIMacro II dibentuk dari empat strain Udang Galah (Macrobrachium rosenbergii de Man 1879) yang secara geografis berasal dari tempat yang berbeda, yakni Strain Barito, Strain Musi, Strain Asahan, dan Ciasem serta Strain GIMacro. (KEPMEN-KP, 2014)

Pada tahun 2015, dari hasil pemuliaan yang telah dilakukan Balai Besar Perikanan Budidaya Air Tawar (BBPBAT) Sukabumi, telah dilakukan pelepasan Udang Galah (Macrobrachium rosenbergii de Man 1879) unggul SIRATU tahun 2015. Siratu merupakan varietas baru Udang Galah (Macrobrachium rosenbergii de Man 1879) yang berasal dari tiga strain induk Udang Galah (Macrobrachium rosenbergii de Man 1879), yaitu induk Udang Galah (Macrobrachium rosenbergii de Man 1879) strain Mahakam, strain Bone dan strain Citanduy (KEPMEN-KP, 2015).

Beberapa upaya yang telah dilakukan untuk memperbaiki strain yang baik, antara lain perkawinan silang strain Udang Galah (Macrobrachium rosenbergii de Man 1879) dapat dilakukan melalui manipulasi lingkungan, genetik hormonal dan pakan. Induk Udang Galah (Macrobrachium rosenbergii de Man 1879) hasil pelepasan Kementerian Kelautan dan Perikanan adalah Strain GIMacro II yang dilepas pada tahun 2014 dan Strain Siratu pada tahun 2015. Kedua strain ini memiliki silsilah yang berbeda, dan perlu melihat tingkat pertumbuham, kelangsungan hidup, dan FCR dari kedua strain tersebut (Rohmana, 2017). 
Tujuan dalam penelitian ini adalah sebagai berikut : 1). Untuk mengetahui pertumbuhan Udang Galah (Macrobrahium rosenbergii de Man 1879) strain Siratu dan strain GIMacro II dan 2). Untuk mengetahui kelangsungan hidup Udang Galah (Macrobrachium rosenbergii de Man 1879) strain Siratu dan strain GIMacro II.

\section{METODE PENELITIAN}

Penelitian ini dilaksanakan selama tiga bulan yang dimulai pada bulan September sampai dengan bulan November 2017 yang dilakukan di Instalasi Pembenihan Udang Galah Balai Besar Perikanan Budidaya Air Tawar (IPUG BBPBAT) Sukabumi, Jalan Raya Cisolok KM. 12 Desa Karang Papak Pelabuhanratu, Provinsi Jawa Barat. Penelitian ini menggunakan Rancangan Acak Lengkap (RAL) dengan 3 taraf perlakuan dan 3 ulangan sebagai berikut :

1. A : Udang Galah Strain Siratu $100 \%$

2. B : Udang Galah Strain GIMacro II $100 \%$

3. C : Udang Galah Strain Siratu $50 \%+$ Strain GIMacro II 50\%

Untuk mengetahui Tingkat Pertumbuhan, Kelangsungan Hidup serta kualitas air pada udang dapat diketahui dengan rumus yang dikemukakan oleh Effendi (1997) dalam Rahmawati (2009) sebagai berikut :

\section{Pertumbuhan}

\section{a. Pertumbuhan Panjang}

Rumus pertumbuhan panjang yang digunakan berdasarkan Effendie (1997) dalam Rahmawati (2009) sebagai berikut :

Keterangan :

$$
\mathbf{P m}=\mathbf{P t}-\mathbf{P o}
$$

$\mathrm{Pm}=$ Panjang rerata udang $(\mathrm{g})$

$\mathrm{Pt} \quad=$ Panjang rerata udang akhir penelitian $(\mathrm{g})$

Po = Panjang rerata udang awal penelitian $(\mathrm{g})$

\section{b. Pertambahan bobot}

Pertumbuhan ikan dapat dihitung dengan menggunakan rumus (Effendi, 1997 dalam Rahmawati, 2009) :

Keterangan :

$$
\mathbf{W m}=\mathbf{W t}-\mathbf{W o}
$$

$\mathrm{Wm}=$ Berat rerata udang $(\mathrm{g})$

$\mathrm{Wt}=$ Berat rerata udang akhir penelitian $(\mathrm{g})$

Wo $=$ Berat rerata udang pada awal penelitian

2. Kelangsungan Hidup (SR)

Kelangsungan hidup (SR) adalah peluang hidup suatu individu dalam waktu tertentu. Tingkat kelangsungan hidup dalam kegiatan ini dihitung menggunakan rumus (Effendi, 1997 dalam Rahmawati, 2009):

$$
\frac{\mathrm{SR}=\mathrm{Nt} X 100 \%}{\text { No }}
$$

Keterangan :

$\mathrm{SR}=$ Kelangsungan Hidup (\%)

$\mathrm{Nt}=$ Jumlah benih yang hidup pada akhir

No = Jumlah benih ditebar awal pemeliharaan

Kualitas air yang diamati pada saat penelitian untuk bahan pendukung adalah Suhu, $\mathrm{DO}$, dan $\mathrm{pH}$. Selama penelitian setiap hari dilakukan pengecekan suhu, $\mathrm{pH}$, dan Oksigen terlarut (DO) 2 kali sehari masing - masing pada pukul 07.00 WIB, dan pukul 17.00 WIB. Untuk Pengukuran Amonia dan Nitrit dilakukan hanya sekali yaitu pada akhir penelitian, pengujian kualitas air dilakukan di Balai Besar Perikanan Air Tawar Sukabumi (Instalasi Pembenihan Udang Galah, 2016).

Data yang diperoleh dari pengamatan disajikan dalam bentuk tabel dan grafik. Analisa data yang dilakukan dalam penelitian ini menggunakan Rancangan Acak Lengkap (RAL). Pengaruh perlakuan ditentukan dengan analisa sidik ragam. Jika dari analisa sidik ragam diketahui bahwa perlakuan strain yang berbeda menunjukkan pengaruh yang berbeda nyata atau sangat nyata akan diuji lanjut apabila Fhitung $>$ Ftabel dan data kualitas air diuji secara deskriptif (Hanafiah 2016).

\section{HASIL DAN PEMBAHASAN}

\section{Pertumbuhan}

\section{a. Panjang Udang Galah (Macrobrachium rosenbergii de Man 1879)}

Berdasarkan sampling yang dilakukan sebanyak 6 kali selama 75 hari penelitian diperoleh panjang rata - rata Udang Galah (Macrobrachium rosenbergii de Man 1879) yang hasilnya dapat dilihat pada Gambar 1

Gambar 1. Pertumbuhan Panjang Rataan Udang Galah (Macrobrachium rosenbergii de Man 1879).

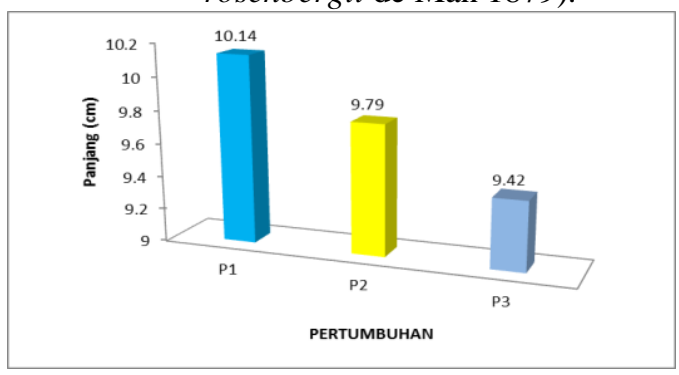

Dari gambar 1 menunjukkan nilai pertumbuhan sampling panjang tertinggi terdapat pada perlakuan P1 (Siratu 100\%) yaitu sebesar $10.14 \mathrm{~cm}$, diikuti perlakuan P2 (GIMacro II 100\%) sebesar 9,79 $\mathrm{cm}$ dan P3 (Siratu 50\% dan GIMacro II 50\%) sebesar 9,42 $\mathrm{cm}$. Berdasarkan pengamatan pertumbuhan panjang Udang Galah (Macrobrachium 
rosenbergii de Man 1879) diperoleh hasil Analisis ANSIRA dapat dilihat pada Tabel 1

Tabel 1. Analisis ANSIRA Pertumbuhan Panjang Udang Galah (Macrobrachium rosenbergii de Man 1879)

\begin{tabular}{|c|c|c|c|c|c|c|}
\hline \multirow[t]{2}{*}{ SK } & \multirow[t]{2}{*}{ DB } & \multirow[t]{2}{*}{ JK } & \multirow[t]{2}{*}{$\mathbf{K T}$} & \multirow[t]{2}{*}{ Fhit } & \multicolumn{2}{|c|}{ Ftabel } \\
\hline & & & & & 0,05 & 0.01 \\
\hline Perlakuan & 2 & 0.78 & 0.37 & $1.85^{\mathrm{tn}}$ & 5.14 & 10.92 \\
\hline Galat & 6 & 1.26 & 0.11 & & & \\
\hline Total & 8 & 2.04 & & & & \\
\hline $\begin{array}{l}\text { Keterangan } \\
\text { KK }\end{array}$ & & $\begin{array}{l}:{ }^{\mathrm{tn}}= \\
=4.6\end{array}$ & (n) & Tid & Tyata & \\
\hline
\end{tabular}

$\begin{array}{ccr}\text { Data } & \text { hasil analisis } & \text { ANSIRA } \\ \text { pertumbuhan } & \text { panjang Udang } & \text { Galah }\end{array}$ (Macrobrachium rosenbergii de Man 1879) dengan perlakuan Strain yang berbeda pada (Tabel 1) menunjukkan $\mathrm{F}_{\text {hitung }}<\mathrm{F}_{\text {tabel }}$ dengan tingkat kepercayaan 5\% dimana $1.85<5,14$, yang artinya berpengaruh tidak nyata antarperlakuan yang berbeda dengan nilai Koefisien Keragaman sebesar 4,69\% maka tidak perlu dilakukan uji lanjut.

Perlakuan P1 (Siratu 100\%) menunjukkan nilai yang tertinggi yaitu 10,14 $\mathrm{cm}$. Hal ini diduga P1 (Siratu 100\%) mengalami pertumbuhan yang relatif lebih cepat dari udang lainnya serta pengaruh dari asal parental strain Siratu tersebut. Hasil ini menandakan sumber genetik dari indukan Udang Galah (Macrobrachium rosenbergii de Man 1879) Strain Siratu memiliki respon pertumbuhan yang dominan. Hal ini diperkuat oleh KEPMEN-KP (2015) yang menyatakan bahwa Strain Siratu memiliki pertumbuhan cepat $33,68 \%$ dari udang biasa. Hal ini diperkuat kembali oleh Rohmana (2017) yang menyatakan bahwa strain Siratu itu diperoleh berdasarkan dari strain Mahakam yang memiliki keunggulan toleransi terhadap salinitas hidup benih tinggi dan strain bone yang memiliki keunggulan pertumbuhan yang baik serta strain Citanduy memiliki tingkat keberhasilan pemijahan yang paling tinggi diantara Strain yang lain.

Menurut Rohmana (2017) menyatakan Strain Siratu memiliki karakter pertumbuhan yang lebih cepat baik pada masa pemeliharaan di hatchery (pembenihan) maupun pembesaran di kolam budidaya, keunggulan lainnya kelangsungan hidup tinggi baik pada fase benih (50-60\%) maupun pada fase pembesaran $(90 \%)$. Lalu toleransi lingkungan ( $\mathrm{pH}$, suhu, salinitas) tinggi yakni sekitar 95\% bebas virus MrNV (Macrobrachium rosenbergii nodavirus), juga memiliki ketahanan terhadap bakteri vibriosis lebih dari $60 \%$. Metode pengembangan yang digunakan yaitu metode persilangan dengan cara mengawinkan ketiga strain tersebut sehingga terdapat 9 kombinasi persilangan, masing-masing kombinasi persilangan akan ditempatkan pada satu kolam. Kemudian $20 \%$ keturunan dari masing-masing kolam akan diambil dan selanjutnya menjadi populasi baru yang menjadi populasi dasar sintetis, yakni populasi buatan sebagai dasar untuk seleksi berikutnya. Metode yang dilakukan lebih kea rah pemuliaan, yakni dengan dengan seleksi individu yang akan dijadikan indukan selanjutnya.

Sedangkan untuk perlakuan P2 (GIMacro II 100\%) yang pertumbuhannya lebih rendah dibandingkan dengan perlakuan P1 (Siratu 100\%) dan lebih tinggi dari P3 (Siratu 50\% dan GIMacro II 50\%) yaitu sebesar 9,79 $\mathrm{cm}$. Hal ini diduga adanya perbedaan pertumbuhan Strain GIMacro II yang tidak merata sehingga terjadinya persaingan dalam perebutan pakan yang menyebabkan ukuran Strain GIMacro II bervariasi. Hal ini diperkuat oleh Iswandi et al (2014), kekurangan pakan akan memperlambat laju pertumbuhan, sehingga dapat menyebabkan kanibalisme, sedangkan kelebihan pakan akan mencemari perairan sehingga udang stres dan menjadi lemah serta nafsu makan udang akan menurun. Menurut Effendi (2004) mengemukakan bahwa pertumbuhan merupakan perubahan bentuk udang, baik panjang maupun berat sesuai dengan perubahan waktu.

GIMacro merupakan varietas Udang Galah (Macrobrachium rosenbergii de Man 1879) hasil seleksi yang merupakan populasi sintetik dari tiga sumber populasi yaitung Kalipucang, Tanjuang Air dan Sungai Musi yang memiliki beberapa keunggulan, diantaranya pada trait pertumbuhan, edible portion maupun kemampuan adaptasi terhadap lingkungan. Udang Galah (Macrobrachium rosenbergii de Man 1879) GIMacro secara resmi dirilis oleh Menteri Kelautan dan Perikanan pada 23 Juli 2001 (KEPMEN-KP, 2014). Ada banyak faktor yang mempengaruhi laju pertumbuhan udang, menurut Huet (1986) dalam Iswandi et al (2014) pertumbuhan udang dipengaruhi oleh beberapa faktor, yaitu internal (Keturunan, umur, dan ketahanan terhadap penyakit) dan eksternal (suhu perairan, besarnya ruang gerak, kualitas air, jumlah dan mutu makanan). Sedangkan hasil pengamatan menunjukkan nilai yang terendah terdapat pada perlakuan P3 (Siratu 50\% dan GIMacro II 50\%) yaitu $9,42 \mathrm{~cm}$. Hal ini diduga pada saat pemberian pakan udang Strain Siratu lebih banyak menyerap pakan yang diberikan sehingga menyebabkan Udang Galah 
(Macrobrachium rosenbergii de Man 1879) Strain GIMacro II pada perlakuan P3 tidak dapat menyerap pakan secara optimal yang menghambat pertumbuhan Udang Galah (Macrobrachium rosenbergii de Man 1879) Strain GIMacro II. Hal ini diperkuat KEPMENKP (2015) yang menyatakan bahwa Strain Siratu dan Strain GIMacro adalah komoditas unggul dalam perikanan budidaya guna menunjang peningkatan produksi perikanan budidaya serta peningkatan produksi udang galah nasional, pendapatan, dan kesejahteraan pembudidaya ikan.

Strain Siratu merupakan varietas baru Udang Galah (Macrobrachium rosenbergii de Man 1879) yang berasal dari tiga strain induk Udang Galah (Macrobrachium rosenbergii de Man 1879), yaitu induk Udang Galah (Macrobrachium rosenbergii de Man 1879) strain Mahakam, strain Bone dan strain Citanduy sedangkan Strain GIMacro II merupakan varietas baru Udang Galah (Macrobrachium rosenbergii de Man 1879) yang berasal dari empat strain Udang Galah (Macrobrachium rosenbergii de Man 1879) yang secara geografis berasal dari tempat yang berbeda, yaitu udang galah dari Barito (Sungai Barito, Kalimantan Selatan), Ciasem (Sungai Ciasem, Jawa Barat), dan Musi (Sungai Ogan, Sumatera Selatan) serta Strain GiMacro (KEPMEN-KP, 2014 dan 2015). Hal ini diperkuat oleh Trijoko et al., (2013) dengan teori penurunan sifat bahwa populasi yang memiliki homozigositas dominan tinggi jika dikawinsilangkan dengan populasi yang memiliki heterozigositas tinggi akan menghasilkan keturunan yang lebih baik.

\section{b. Bobot Udang Galah (Macrobrachium rosenbergii de Man 1879) \\ Hasil pengamatan terhadap} peningkatan pertambahan bobot Udang Galah (Macrobrachium rosenbergii de Man 1879) pada masing-masing perlakuan dapat dilihat pada Gambar 2.

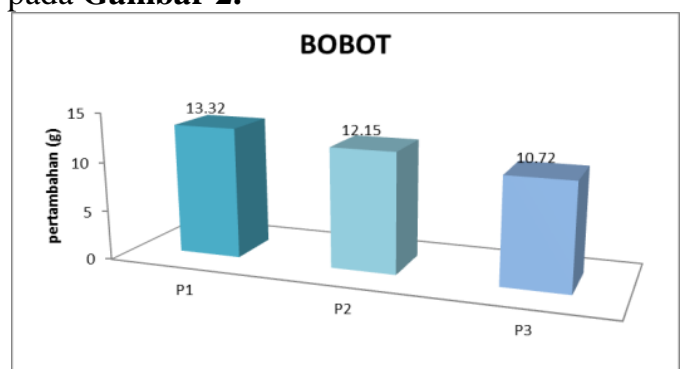

Gambar 2. Pertumbuhan Bobot Rataan Perlakuan Udang Galah (Macrobrachium rosenbergii de Man 1879) selama pengamatan.
Berdasarkan pada Gambar 2 di atas menunjukkan nilai pertambahan berat bobot rata-rata tertinggi terdapat pada perlakuan P1 (Siratu 100\%) sebesar 13,32 gram, diikuti dengan perlakuan P2 (GIMacro II 100\%) yaitu sebesar 12,15 gram, dan perlakuan P3 (Siratu $50 \%$ dan GIMacro II 50\%) yang terendah yaitu sebesar 10,72 gram. Berdasarkan pengamatan pertambahan bobot Udang Galah (Macrobrachium rosenbergii de Man 1879) diperoleh hasil dapat dilihat pada Tabel 2.

Tabel 2. Ansira Pertambahan Bobot Udang Galah (Macrobrachium rosenbergii de Man 1879)

\begin{tabular}{|c|c|c|c|c|c|c|}
\hline \multirow[t]{2}{*}{ SK } & \multirow[t]{2}{*}{ DB } & \multirow[t]{2}{*}{ JK } & \multirow[t]{2}{*}{ KT } & \multirow[t]{2}{*}{ Fhit } & \multicolumn{2}{|c|}{ Ftabel } \\
\hline & & & & & $\mathbf{0 , 0 5}$ & $\mathbf{0 , 0 1}$ \\
\hline Perlakuan & 2 & 10.15 & 5.07 & $1.98^{\mathrm{tn}}$ & 5.14 & 10.92 \\
\hline Galat & 6 & 15.41 & 2.57 & & & \\
\hline Total & 8 & 25.56 & & & & \\
\hline Keterangan & & $:{ }^{\mathrm{tn}}: \mathrm{Be}$ & iga & Tidil & ata & \\
\hline
\end{tabular}

Data hasil Ansira pertambahan bobot Udang Galah (Macrobrachium rosenbergii de Man 1879) dengan perlakuan Strain yang berbeda pada (Tabel 2) menunjukkan $\mathrm{F}_{\text {hitung }}<$ $\mathrm{F}_{\text {tabel }}$ dengan tingkat kepercayaan $5 \%$ dimana $1.98<5,14$, yang artinya berpengaruh tidak nyata antar perlakuan yang berbeda maka tidak perlu dilakukan uji lanjut.

Pada perlakuan P1 (Siratu 100\%) tingkat pertambahan berat tertinggi dari perlakuan lain yaitu dengan berat 13,32 gram. Hal ini diduga pada perlakuan P1 selama masa pemeliharaan jumlah pakan yang diberikan dapat direspon dengan baik oleh udang dan pemberian pakan yang sesuai dengan kebutuhan udang. Hal ini diperkuat oleh Zaidy (2007) dalam Erlando et al (2015) yang menyatakan bahwa pakan yang masuk ke dalam tubuh udang akan digunakan sebagai sumber energi (metabolisme) untuk menggerakan semua fungsi tubuh dan bahan untuk pembangunan biomassa tubuh (anabolisme). Hal ini didukung juga oleh pernyataan Effendie (1986) dalam Iswandi et al (2014) yang mengemukakan bahwa pertumbuhan adalah perubahan bentuk udang baik panjang maupun berat sesuai dengan perubahan waktu.

Sedangkan untuk perlakuan P2 (GIMacro II 100\%) yang laju pertumbuhannya lebih rendah dari perlakuan P1 (Siratu 100\%) dan lebih tinggi dari perlakuan P3 (Siratu 50\% dan GIMacro II 50\%) yaitu seberat 12,15 gram. Hal ini diduga masih kurangnya tingkat pertumbuhan, jumlah pakan yang diberikan tidak semuanya termakan oleh udang, maka dari itu pakan yang dikonsumsi tidak cukup untuk mendapatkan pertumbuhan optimal. Hal ini 
dikuatkan oleh Huet, (1986) dalam Iswandi et al (2014), menyatakan bahwa pertumbuhan udang dapat terjadi jika jumlah makanan yang diberikan lebih banyak dari jumlah makanan yang diperlukan untuk pemeliharaan tubuh. Menurut Satyani et al (2010) dalam Batubara dan Gustianty (2016), Pertumbuhan adalah perubahan ikan/udang yang dilihat dari berat maupun panjang tubuh dalam waktu tertentu.

Sedangkan pada perlakuan P3 (Siratu $50 \%$ dan GIMacro 50\%) didapatkan hasil pertumbuhan berat terendah dibandingkan perlakuan P1 (Siratu 100\%) dan P2 (GIMacro II $50 \%$ ) yaitu dengan bobot akhir 10,72 gram. Hal ini diduga pada perlakuan P3 (Siratu $50 \%$ dan GIMacro II 50\%) merupakan campuran dari kedua strain yang berbeda yaitu $50 \%$ Strain Siratu dan 50\% Strain GIMacro II sehingga saat pengambilan sampling secara acak menghasilkan laju pertambahan panjang dan berat yang berbeda karena kedua strain memiliki keunggulan berbeda. Hal ini diperkuat oleh (KEPMEN-KP, 2014 dan 2015) yang menyatakan bahwa Strain Siratu memiliki tingkat kelangsungan hidup yang tinggi, mengurangi durasi pemeliharaan larva, dan konversi pakan yang rendah dan Strain GIMacro II memiliki keunggulan laju pertumbuhan dari udang biasa pada umumnya. Menurut Hadie dan Hadie (2002), yang menyatakan bahwa pertumbuhan terjadi pada makhluk hidup apabila jumlah makanan yang dimakan melebihi kebutuhan untuk mempertahankan hidupnya.

\section{Kelangsungan Hidup}

Hasil pengamatan kelangsungan hidup Udang Galah (Macrobrachium rosenbergii de Man 1879) pada masing-masing perlakuan terdapat pada Gambar 3

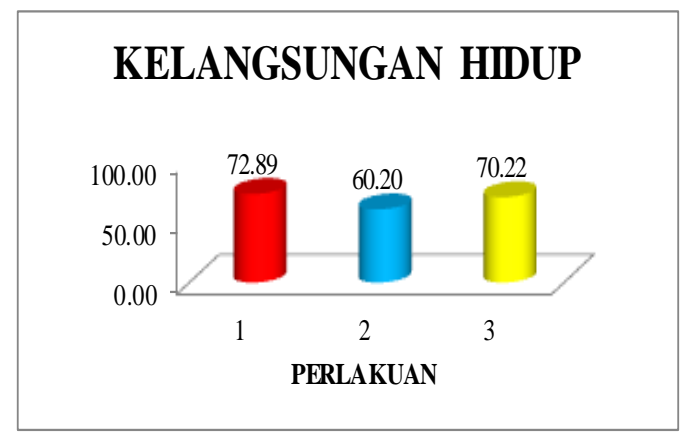

Gambar 3. Kelangsungan Hidup Udang Galah (Macrobracium rosenbergii de Man 1879).

Gambar 3 menunjukkan bahwa kelangsungan hidup tertinggi terdapat pada perlakuan P1 sebesar 72,89\%, diikuti perlakuan P3 yaitu 70,22\% dan kelangsungan hidup yang terendah ada pada perlakuan P2 sebesar $60,22 \%$. Berdasarkan pengamatan kelangsungan hidup Udang Galah (Macrobrachium rosenbergii de Man 1879) diperoleh hasil Analisis ansira dapat dilihat pada Tabel 3.

Tabel 3. Hasil Analisis ANSIRA Kelangsungan Hidup Udang Galah (Macrobrachium rosenbergii de Man 1879).

\begin{tabular}{lcccccc}
\hline \multicolumn{1}{c}{ SK } & DB & JK & KT & Fhit & \multicolumn{2}{c}{ Ftabel } \\
\cline { 5 - 7 } & & & & & $\mathbf{0 , 0 5}$ & $\mathbf{0 . 0 1}$ \\
\hline Perlakuan & 2 & 1.38 & 0.37 & $3.48^{\text {tn }}$ & 5.14 & 10.92 \\
Galat & 6 & 0.74 & 0.11 & & & \\
\hline \multicolumn{1}{c}{ Total } & $\mathbf{8}$ & $\mathbf{2 . 1 2}$ & & & & \\
\hline
\end{tabular}

Keterangan $:{ }^{\text {tn }}=$ Berpengaruh Tidak Nyata

$\begin{array}{cccr}\text { Data } & \text { hasil } & \text { analisis } & \text { ANSIRA } \\ \text { kelangsungan } & \text { hidup } & \text { Udang } & \text { Galah }\end{array}$ (Macrobrachium rosenbergii de Man 1879) dengan perlakuan Strain yang berbeda pada (Tabel 3) menunjukkan $\mathrm{F}_{\text {hitung }}<\mathrm{F}_{\text {tabel }}$ dengan tingkat kepercayaan 5\% dimana $1.98<5,14$, yang artinya, berpengaruh tidak nyata antarperlakuan yang berbeda. Dari hasil perhitungan kelangsungan hidup diperoleh nilai P1 yaitu 72,89\%, P2 yaitu 60,20\%, dan P3 yaitu $70,22 \%$.

Pada perlakuan P1 (Siratu 100\%) tingkat kelangsungan hidup tertinggi dari perlakuan lain yaitu $72,89 \%$. Hal ini diduga Strain Siratu memiliki laju pertumbuhan yang merata sehingga tidak ada dominasi udang yang berukuran besar yang memangsa udang yang kecil sehingga menyebabkan kelangsungan hidup terjaga, selain itu rendahnya kanibalisme, kegagalan ganti kulit dan ketahanan terhadap penyakit. Hal ini diperkuat oleh pendapat Batubara dan Gustianty (2016) yang berpendapat bahwa kematian pada udang disebabkan karenanya rendahnya adaptasi Udang Galah (Macrobrachium rosenbergii de Man 1879) terhadap ruang/wadah dan pakan yang diberikan, kegagalan moulting serta kanibalisme. Menurut adegboye (1981) dalam Erlando et al (2015), menyatakan bahwa pada sebelum dan sesudah ganti kulit (moulting), udang melakukan starvasi (tidak makan) sehingga aktivitasnya sangat tergantung dari cadangan energi makanan yang ada di dalam jaringan. Anggoro (1992) dalam Erlando et al (2015), proses moulting yang tidak bersamaan diantara udang yang satu dengan lainnya cenderung menyebabkan terjadinya kanibalisme terhadap udang yang sedang moulting dan selanjutnya mengakibatkan kematian.

Sedangkan pada perlakuan P3 (Siratu $50 \%$ dan GIMacro II 50\%) yang kelangsungan hidupnya masih kurang dari P1 (Siratu 100\%) dan lebih tinggi dari P2 (GIMacro II 100\%) 
yaitu $70,22 \%$. Hal ini diduga pada perlakuan $\mathrm{P} 3$ (Siratu 50\% dan GIMacro II 50\%) merupakan campuran dari kedua strain yang berbeda yaitu $50 \%$ Strain Siratu dan 50\% Strain GIMacro II sehingga keunggulan dari kedua Strain terutama strain Siratu menyebabkan kelangsungan Hidup P3 (Siratu 50\% dan GIMacro II 50\%). Hal ini diperkuat oleh KEPMEN-KP (2015) yang menyatakan bahwa Strain Siratu unggul dalam kelangsungan hidup dan mengurangi durasi pemeliharaan larva. Menurut Effendi (2004) mengemukakan bahwa tingkat kelangsungan hidup suatu populasi udang merupakan nilai persentasi jumlah udang yang berpeluang untuk hidup selama masa pemeliharaan tertentu dalam suatu wadah budidaya. Said (1978) dalam Iswandi et al (2014) menambahkan bahwa udang galah (Macrobrachium rosenbergii de Man 1879) pascalarva yang berasal dari satu induk dalam periode produksi yang sama dan tempat relatif homogen menunjukkan pertumbuhan yang bervariasi, semakin lama pemeliharaan, perbedaan semakin besar, variasi pertumbuhan yang terjadi cenderung dikarenakan oleh faktor genetik.

Sedangkan untuk Perlakuan P2 (GIMacro II 100\%) yang kelangsungan hidupnya rendah yaitu sebesar $60,20 \%$. Hal ini diduga laju pertumbuhan GIMacro yang cepat yang menyebabkan Udang Galah (Macrobrachium rosenbergii de Man 1879) memiliki capit yang panjang dan besar sehingga capit tersebut bisa melukai dan merobek kulit Udang Galah (Macrobrachium rosenbergii de Man 1879) yang mengalami pergantian kulit (moulting) sehingga mengakibatkan kegagalan ganti kulit (moulting). Pada saat moulting, kulit udang hanya terlepas sebagian keadaan ini tentunya membutuhkan banyak energi sehingga kematian udang disebabkan karena kehabisan energi saat ganti kulit, saat moulting umumnya udang lemah dan tidak aktif bergerak (malas bergerak) keadaan ini menyebabkan udang dimangsa oleh udang lainnya (kanibalisme). Menurut Ferraris et al (1987) dalam Batubara dan Gustianty (2016), kematian akibat gangguan moulting berkaitan dengan terjadinya gangguan osmolaritas internal, kehabisan energi untuk ganti kulit serta berkurangnya daya pemanfaatan pakan.

Gagal moulting bisa diakibatkan oleh kondisi cangkang yang keras sehingga proses pergantian kulit berikutnya akan sulit dilakukan dan keadaan ini akan menghambat pertumbuhan udang (Ali dan Waluyo, 2015). Lambatnya proses pengerasan kulit atau lamanya waktu yang dibutuhkan sehingga terbentuknya kulit yang baru menyebabkan udang tidak segera aktif makan, semakin lama kulit baru terbentuk maka udang terus tidak aktif makan keadaan ini tentunya akan menjadi penyebab kematian udang yang dipelihara (Zaidy, 2007 dalam Batubara dan Gustianty, 2016).

\section{Kualitas Air}

Pengamatan kualitas air yang dilakukan selama penelitian meliputi $\mathrm{pH}$, suhu, oksigen (DO), Amonia (NH3), Nitrit (NO2). Kisaran data yang diperoleh dari pengambilan sampel setiap perlakuan dapat dilihat pada Lampiran 4. Secara keseluruhan kisaran parameter kualitas air tersebut masih berada dalam kisaran normal dan layak bagi kehidupan ikan. Hasil kisaran pengamatan kualitas air selama penelitian pada Tabel 4.

\begin{tabular}{lcccc} 
Tabel 4. Parameter Kualitas Air Selama Penelitian & Sumber \\
\cline { 2 - 5 } \multicolumn{1}{c}{ Parameter } & P1 & Perlakuan & PNI \\
\hline pH & $7,05-7,44$ & $7,06-7,45$ & $7,10-7,46$ & $6,5-8,5$ \\
DO (mg/L) & $3,9-8,1$ & $3,8-6,9$ & $3,8-6,9$ & $>5(\mathrm{mg} / 1)$ \\
Suhu $\left({ }^{\circ} \mathrm{C}\right)$ & $27,0-33,2$ & $27,3-33,1$ & $27,1-32,9$ & $28^{\circ} \mathrm{C}-30^{\circ} \mathrm{C}$ \\
Amonia $(\mathrm{mg} / \mathrm{L})$ & 0,30 & 0,27 & 0,41 & $<0,1$ \\
Nitrit $(\mathrm{mg} / \mathrm{L})$ & 0,046 & 0,038 & 0,066 & $<5$
\end{tabular}

Sumber : Data Penelitian, 2017

Berdasarkan pengamatan kualitas air yang dilakukan selama penelitian meliputi $\mathrm{pH}$, oksigen (DO), suhu, amoniak $\left(\mathrm{NH}_{3}\right)$, nitrit $\left(\mathrm{NO}_{2}\right)$. Menurut Cahyono (2009) dalam Fuady et al (2013), faktor yang mempengaruhi tinggi rendahnya kelangsungan hidup dalam budidaya adalah faktor abiotik dan biotik. Faktor abiotik diantaranya adalah faktor fisika, kimia air suatu perairan atau sering disebut dengan kualitas air. Kualias air yang baik akan menyebabkan proses fisiologi dalam tubuh biota berjalan dengan

baik, sehingga mendukung pertumbuhan dan kelulushidupan biota.

\section{1. $\mathbf{p H}$}

Pengamatan $\mathrm{pH}$ air selama penelitian Udang Galah (Macrobrachium rosenbergii de Man) berkisar antara 7,05 - 7,46. Kisaran kualitas air selama penelitian berada dalam kisaran yang baik untuk kehidupan udang galah dengan nilai 7,05 - 7,44 untuk perlakuan P1, Kemudian untuk perlakuan P2 pada kisaran 7,06 - 7,45 dan perlakuan P3 pada kisaran 7,10 $-7,46$. Hal ini juga dikuatkan oleh Spott (2000) 
dalam Kisworo dan Mukhlisah (2015) yang mengemukakan bahwa derajat keasaman berkisar antara 7,2 - 8,4. Keasaman $\mathrm{pH}$ merupakan indikator tersedianya kadar $\mathrm{CaCo}_{3}$ (kesadahan). Senyawa tersebut merupakan faktor yang penting pada proses pergantian kulit (moulting) (Hadie dan Hadie, 1993).

Tingkat keasaman $(\mathrm{pH})$ perairan merupakan parameter kualitas air yang penting dalam ekosisem perarairan. Perubahan $\mathrm{pH}$ ditentukan oleh aktivitas fotosintesis dan respirasi ekosistem. Nilai $\mathrm{pH}$ perairan merupakan parameter yang dikaitkan dengan karbondioksida $\left(\mathrm{CO}_{2}\right)$ dalam ekosistem. Semakin tinggi konsentrasi karbondioksida, $\mathrm{pH}$ perairan semakin rendah. Perubahan $\mathrm{pH}$ dapat mempunyai akibat buruk terhadap kehidupan biota, baik secara langsung maupun tidak langsung. Akibat langsung adalah kematian pada ikan, burayak, telur dan lainnya serta mengurangi produktivitas primer. Akibat tidak langsung adalah perubahan toksisitas zat-zat yang ada di dalam perairan. Dampak perubahan $\mathrm{pH}$ pada udang yaitu terganggunya proses metabolisme udang, udang mudah terserang penyakit, dan pertumbuhan yang menurut akibat stress yang dialami udang (Izzati, 2008).

\section{Suhu}

Hasil pengukuran suhu menunjukkan nilai suhu pagi hari untuk perlakuan $\mathrm{P} 1$ adalah $27^{\circ} \mathrm{C}-33,2^{\circ} \mathrm{C}$ untuk perlakuan $\mathrm{P} 2$ adalah $27,3^{\circ} \mathrm{C}-33,1^{\circ} \mathrm{C}$ dan untuk perlakuan $\mathrm{P} 3$ adalah $27,1^{\circ} \mathrm{C}-32,9^{\circ}$. Suhu merupakan faktor lingkungan yang sangat berpengaruh terhadap pertumbuhan, perkembangan dan kelulushidupan udang. Suhu yang dapat ditoleransi Udang Galah (Macrobrachium rosenbergii de Man 1879) berkisar antara 26 $30^{\circ} \mathrm{C}$ (Kisworo et al, 2015).

Apabila suhu terlalu dingin menyebabkan penurunan nafsu makan udang yang mempengaruhu pertumbuhan dan penambahan bobot menjadi lambat, menekan respon kekebalan udang sehingga udang menjadi lebih rentan dari serangan bibit penyakit. Apabila suhu terlalu panas akan menurunkan konsentrasi oksigen yang terlarut sehingga mengganggu kondisi fisiologi udang karena beberapa fungsi organ terganggu seperti metabolisme, meningkatkan daya toksisitas bahan-bahan terlarut yang berbahaya, pada suhu yang ekstrem terjadi kematian pada udang. Menurut Spotts (2000) dalam Kisworo dan Mukhlisah (2015), kisaran suhu terbaik untuk kehidupan Udang Galah (Macrobrachium rosenbergii de Man 1879) $26-30^{\circ} \mathrm{C}$ dan pada suhu $22-32^{\circ} \mathrm{C}$. dengan demikian hasil pengukuran suhu air masih dalam batasan normal dan mendukung untuk kehidupan Udang Galah (Macrobrachium rosenbergii de Man 1879).

\section{Oksigen Terlarut (DO)}

Hasil pengukuran DO menunjukkan nilai oksigen terlarut pagi hari untuk perlakuan P1 adalah 3,9 mg/L - 8,1 mg/L untuk perlakuan $\mathrm{P} 2$ adalah 3,8 mg/L - 6,9 $\mathrm{mg} / \mathrm{L}$ dan untuk perlakuan $\mathrm{P} 3$ adalah 3,8 mg/L - 6,9 mg/L. Oksigen terlarut selama penelitian masih dalam batas minimal untuk kelangsungan hidup udang hal ini juga dikuatkan oleh Hadie et al, (1985) dalam Kisworo dan Muklisah (2015) yang menyatakan bahwa Udang Galah (Macrobrachium rosenbergii de Man 1879) termasuk hewan yang bersifat sensitive terhadap kadar oksigen terlarut. DO adalah sejumlah oksigen yang terikat (terlarut) dengan partikel air. Oksigen sangat dibutuhkan oleh semua makhluk hidup untuk beraktifitas, pertumbuhan, reproduksi, dan lain-lain. DO yang optimal untuk budidaya udang adalah 4-8 ppm. DO dapat dihasilkan dari proses fotosintesis phytoplankton pada siang hari dan dari penggunaan kincir air serta aerator pada malam hari. DO dipengaruhi oleh suhu, $\mathrm{pH}$ dan bahan organik. Semakin tinggi suhu, DO akan semakin rendah. DO yang terlalu rendah dapat disebabkan oleh lumut, plankton yang mati, kekentalan air serta jumlah bahan organik yang menumpuk. Menurut Hadie dan Hadie (1993), merupakan sumber respirasi (pernapasan) bagi larva, oleh karenanya harus terdapat di dalam media.

\section{Amonia $\left(\mathrm{NH}_{3}\right)$}

Pengukuran kadar amonia menunjukkan nilai untuk perlakuan $\mathrm{P} 1$ adalah $0,30 \mathrm{mg} / \mathrm{L}$, untuk perlakuan $\mathrm{P} 2$ adalah $0,27 \mathrm{mg} / \mathrm{L}$ dan untuk perlakuan P3 adalah 0,41 $\mathrm{mg} / \mathrm{L}$. Dari hasil pengukuran kadar amonia selama penelitian masih dalam batas minimal untuk kelangsungan hidup. Hal ini diperkuat oleh Tidwell et al (2002) dalam Tantri (2014) yang menyatakan bahwa kadar amonia yang terlalu tinggi dapat menghambat pertumbuhan dalam jangka dapat menyebabkan kematian. Hal ini diperkuat juga oleh Hadie dan Hadie, (1993) yang mengemukakan amonia adalah senyawa yang bersifat racun yang berasal dari hasil penguraian protein secara kimiawi.

Menurut Umroh (2007), amonia sangat penting dalam budidaya, amonia dalam bentuk ammonium dapat dimanfaatkan oleh tumbuhan air melalui proses asimilasi dan digunakan sebagai sumber energi oleh mikroorganisme nitrifikasi dalam oksidasi amonia menjadi $\mathrm{NO}_{2}$ kemudian dilanjutkan menjadi $\mathrm{NO}_{3}$. Akan tetapi kadar amonia yang terlalu tinggi berpengaruh negatif terhadap kehidupan organisme akuatik, yaitu secara langsung dapat mematikan 
organisme perarairan melalui pengaruhnya permeabilitas sel, mengurangi kosentrasi ion dalam tubuh, meningkatkan konsumsi oksigen dalam jaringan, merusak insang, dan mengurangi kemampuan darah. Meningkatnya kadar amonia secara tidak langsung dapat mematikan pasca larva udang sehingga mempengaruhi kelulusanhidupan udang karena amonia berbahaya untuk udang dan merupakan pesaing oksigen pada daya serap darah. Sedangkan Menurut Yudha (2009) dalam Silaban, et al (2012), ikan tidak dapat mentoleransi konsentrasi amonia yang terlalu tinggi karena dapat mengganggu proses pengingkatan oksigen oleh darah dan pada akhirnya dapat mengakibatkan kematian.

\section{Nitrit $\left(\mathrm{NO}_{2}\right)$}

Pengukuran kadar amonia menunjukkan nilai untuk perlakuan $\mathrm{P} 1$ adalah $0,046 \mathrm{mg} / \mathrm{L}$, untuk perlakuan $\mathrm{P} 2$ adalah $0,038 \mathrm{mg} / \mathrm{L}$ dan untuk perlakuan P3 adalah 0,066 mg/L. Nitrit dapat merupakan hasil lanjutan dari amonia yang diubah oleh bakteri atau proses kimiawi secara langsung. Pada konsentrasi tinggi, nitrit akan bersifat racun bagi udang. Namun dibandingkan dengan amonia, toleransi udang terhadap nitrit lebih tinggi. Jika senyawa nitrit yang ada di dalam tambak terlalu banyak akan memicu yang namanya ledakan plankton dan mikroorganisme lainnya. Untuk awalnya jenis fitoplankton akan memanfaatkannya dalam proses pertumbuhan, tetapi selanjutnya akan ada jenis zooplankton yang akan memakan fitoplankton tersebut, yang nantinya akan membuat ledakan jumlah zooplankton. Dengan banyaknya zooplankton, maka jumlah oksigen yang terlarut dalam air akan semakin sedikit karena akan menjadi rebutan bagi banyak mikroorganisme di dalam tambak. Dengan semua kondisi tersebut, maka udang yang dibudidayakan akan terkena dampak langsung dari berkurangnya kadar oksigen yang ada di dalam tambak. Kadar nitrit yang dapat ditoleransi dalam budidaya udang yaitu kurang dari $5 \mathrm{mg} / \mathrm{l}$ (Tantri, 2014).

\section{IV.KESIMPULAN DAN SARAN}

\section{Kesimpulan}

Berdasarkan hasil penelitian yang telah dilakukan, dapat disimpulkan bahwa :

a. Pertumbuhan P1 (Strain Siratu 100\%) dengan panjang hasil yang lebih baik terhadap parameter pertumbuhan panjang rata-rata Udang Galah (Macrobrachium rosenbergii de Man 1879) $10,14 \mathrm{~cm}$ dan berat 19,75 gram. b. Tingkat kelangsungan hidup Udang Galah (Macrobrachium rosenbergii de Man 1879) selama penelitian diperoleh hasil P1 (Strain Siratu 100\%) menunjukkan nilai kelangsungan hidup sebesar 72,89\%.

\section{Saran}

Perlu kajian penelitian lebih lanjut antara kedua strain terhadap parameter lain yaitu tingkat kematangan gonad pada kedua strain sehingga dapat memberikan informasi lebih dalam antara kedua Strain.

\section{DAFTAR PUSTAKA}

Ali, F dan A. Waluyo. 2015. Tingkat Kelangsungan Hidup dan Pertumbuhan Udang Galah (Macrobrachium rosenbergii de Man) Pada Media Bersalinitas. Limnotek 22 (1) : 42 - 51.

Badan Pusat Statistik. 2016. Statistik Sumber Daya Laut dan Pesisir. Subdirektorat Statistik Lingkungan Hidup. Jakarta.

Batubara, J.P dan Gustianty, L.R. 2016. Laju Pertumbuhan dan Kelangsungan Hidup Udang Galah (Macrobrachium rosenbergii de Man) Skala Laboratorium. Universitas Asahan. Sumatera Utara

Effendi, I. 2004. Pengantar Akuakultur. Penebar Swadaya. Jakarta.

Erlando, G., Rusliadi., Mulyadi. 2015. Increasing Calcium ( $\mathrm{CaO}$ ) to Accelarate Moulting and Survival Rate Vannamei Shrimp (Litopenaeus Vannamei). Universitas Riau. Riau.

Evan, Y.2009. Uji Ketahanan Beberapa Strain Larva Udang Galah Terhadap Bakteri Vibrio Harveyi. Skripsi. Institut Pertanian Bogor. Bogor.

Hadie, LE dan W. Hadie. 2002. Budidaya Udang Galah GIMacro Di Kolam Irigasi, Sawah, dan Tambak. Penebar Swadaya.

Hadie, W. dan Hadie.L.H. 1993. Pembenihan Udang Galah Usaha Industri Rumah Tangga. Cetakan Pertama. Kanisius. Yogyakarta.

Hanafiah, K.A. 2016. Rancangan Percobaan Teori dan Aplikasi. Edisi Ketiga.Cet-16. Rajawali Pers. Jakarta.

Iswandi, N., Rusliandi. dan Putra, I. 2014. Growth and Survival Rate of Giants Prawns (Macrobrachium rosenbergii) Universitas Riau. Riau.

Izzati, M. 20028. Perubahan Konsentrasi Oksigen Terlarut dan pH Perairan Tambak Setelah Penambahan Rumput Laut Sargassum Plagyophyllum dan 
Ekstraknya. Universitas Diponegoro. Semarang.

Kementerian Kelautan dan Perikanan. 2014. Pelepasan Udang Galah GIMacro II. Keputusan Menteri Kelautan dan Perikanan Republik Indonesia. Jakarta

Kementerian Kelautan dan Perikanan No. 25. 2015. Pelepasan Udang Galah Siratu. Keputusan Menteri Kelautan dan Perikanan Republik Indonesia. Jakarta.

Kisworo, Y. dan Mukhlisah. 2015. Performa Stock Parental Udang Galah Dari Muara Sungai Barito, Kintap dan Pagatan Sebagai Tetua Pada Sistem Seleksi Induk Unggul Lokal. Ziraa'ah. Vol 40 (1) : 25 - 30.

Priyono,S.B., Sukardi., dan Harianja, S.M. 2011. Pengaruh Shelter Terhadap Perilaku dan Pertumbuhan Udang Galah (Macrobrachium rosenbergii de Man). Jurnal Perikanan 13 (2) : 78 - 85.

Rahmawati, P.A. 2009. Evaluasi Kelangsungan Hidup dan Pertumbuhan Udang Galah Strain Sulawesi, Jawa dan Jenerik Pada Media Asam. Skripsi. Fakultas Perikanan dan Ilmu. Institut Pertanian Bogor. Bogor.

Rohmana, D. 2017. Inovasi Produksi Udang Galah. Departemen Kelautan dan Perikanan. Direktorat Jenderal Perikanan Budidaya, Balai Besar Perikanan
Budidaya Air Tawar. Instalasi Pembenihan Udang Galah. Sukabumi.

Silaban, T.F. Limin, S. dan Suparno. 2012. dalam Peningkatan Kinerja Filter Air untuk Menurunkan Konsentrasi Amonia Pada Pemeliharaan Ikan Mas (Cyprinus Carpio). E-Journal Rekayasa dan Teknologi Budidaya Perairan. 1(1) : 47 56.

Sutjinurani, T., Buwono.D.I., dan Andriani.Y. 2013. Kombinasi Pemberian Artemia sp. dan Kuning Telur Bebek Terhadap Kelangsungan Hidup dan Pertumbuhan Benih Udang Galah (Macrobrachium rosenbergii de Man). Jurnal Perikanan dan Kelautan. 4(3) : 301 - 311.

Tantri, A,F. 2014. Penambahan Lisin Pada Pakan Komersial Terhadap Retensi Protein dan Retensi Energi Udang Galah (Macrobrachium rosenbergii). Skripsi. Fakultas Perikanan dan Kelautan. Universitas Airlangga. Surabaya.

Trijoko, Handayani.N.S.N., Feranisa.A. 2013. Karakterisasi Morfologi dan Diversitas Genetik Hasil Persilangan Macrobrachium rosenbergii (De Man, 1879) Populasi Samas, Bone, dan Sintetis. Jurnal Sain Veteriner. 31(2). ISSN : 0126-0421 